\title{
EFEKTIVITAS MODEL PEMBELAJARAN PROCESS ORIENTED GUIDED INQUIRY LEARNING (POGIL) TERHADAP KEMAMPUAN KOMUNIKASI MATEMATIS
}

\author{
'Putri Yulia, ${ }^{2}$ Maya Riskayani, ${ }^{3}$ Selvia Erita \\ 1,2,3 Tadris Matematika Institut Agama Islam Negeri Kerinci \\ putriyuliamz@gmail.com
}

\begin{abstract}
This study aims to find out (1) the POGIL learning model effective on mathematical communication skills. (2) conventional learning models are effective against mathematical communication skills. (3) the difference between the POGIL learning model and the conventional model of mathematical communication skills. This research is a quasiexperimental research with the research design of The Nonequivalent Posttest Only Control Group Design. The population in this study is all students of grade VII MTS Negeri 02 Kerinci. This study's sample consisted of an experimental class and a control class selected by a random sampling cluster. The research instrument is a test $f$ mathematical communication ability, and the data is analyzed using one-sample t-test statistics and independent t-test samples. This study shows that (1) the POGIL learning model is effective on mathematical communication skills. (2) conventional learning models are ineffective against mathematical communication skills. (3) there is a difference between the POGIL learning model and the conventional model of mathematical communication skills.
\end{abstract}

Keywords: The POGIL, mathematical communication skills, learning effectivity

\begin{abstract}
ABSTRAK Penelitian ini bertujuan untuk mengetahui (1) model pembelajaran POGIL efektif terhadap kemampuan komunikasi matematis. (2) model pembelajaran konvensional efektif terhadap kemampuan komunikasi matematis. (3) perbedaan antara model pembelajaran POGIL dengan model konvensional terhadap kemampuan komunikasi matematis. Penelitian ini merupakan penelitian Quasi Eksperimen dengan rancangan penelitian The Nonequivalent Posttest Only Control Group Design. Populasi dalam penelitian ini adalah seluruh peserta didik kelas VII MTS Negeri 02 Kerinci. Sampel dalam penelitian ini terdiri dari kelas eksperimen dan kelas kontrol dipilih secara cluster random sampling. Instrumen penelitian adalah tes kemampuan komunikasi matematis dan data dianalisis menggunakan statistik uji one sample t-test dan independent sample t-test. Hasil penelitian ini menunjukkan bahwa (1) model pembelajaran POGIL efektif terhadap kemampuan komunikasi matematis. (2) model pembelajaran konvensional tidak efektif terhadap kemampuan komunikasi matematis. (3) terdapat perbedaan antara model pembelajaran POGIL dengan model konvensional terhadap kemampuan komunikasi matematis.
\end{abstract}

Kata-kata Kunci : POGIL, kemampuan komunikasi matematis, efektifitas pembelajaran 


\section{PENDAHULUAN}

Pendidikan merupakan proses perubahan sikap dan tingkah laku seseorang atau kelompok orang dalam usaha mendewasakan manusia melalui upaya pengajaran dan pelatihan (Navia \& Yulia, 2017). Pendidikan sebagai suatu bentuk kegiatan manusia dalam kehidupannya juga menempatkan tujuan sebagai suatu yang hendak dicapai. Pendidikan matematika menggiring untuk berfikir logis dan sistematis karena kemampuan penalaran logis berperan penting dalam matematika (Sari, 2020)

Proses pembelajaran matematika memerlukan penerapan inovasi metode, strategi, dan memerlukan pembelajaran yang mampu membuat peserta didik bergairah dalam mengikuti pembelajaran matematika (Yulia \& Luqman, 2016). Menurut National Council of Teachers of Mathematics (NCTM) dalam Hasratuddin (2014) menetapkan lima komponen Principles and Standars for School Mathematics yaitu: (1) komunikasi matematika (mathematical communication), (2) penalaran matematika (mathematical reasoning), (3) pemecahan masalah matematika (mathematical problem solving), (4) mengaitkan ide-ide matematika (mathematical connections), dan (5) representasi matematika (mathematical representation). Sehingga salah satu diantaranya yaitu komunikasi matematika.

Komunikasi matematis adalah suatu keterampilan penting yang harus dimiliki peserta didik dalam belajar matematika, sehingga peserta didik mampu mengekspresikan ide- ide matematika yang berasal dari argumennya kepada teman, guru dan lainnya melalui bahasa lisan dan tulisan (Hasratuddin, 2014). Sedang menurut Sumarmo dalam Deswita (2018) mengatakan bahwa kemampuan komunikasi matematis merupakan komponen penting dalam belajar matematika, sebagai alat untuk bertukar ide, dan mengklafikasi pemahaman matematis.

Komunikasi dapat diartikan sebagai proses menyampaikan pesan dari seseorang kepada orang lain baik secara lansung (lisan) ataupun tidak langsung (melalui Media) (Handayani, dkk, 2014). Jadi melalui komunikasi ide dapat dicerminkan, diperbaiki, didiskusikan, dan dikembangkan. Proses komunikasi juga membantu membangun makna dan juga dapat menjelaskan ide. Lestari (2015) mengemukakan kemampuan komunikasi matematis adalah kemampuan menyampaikan gagasan/ide matematis baik secara lisan maupun tulisan serta kemampuan memahami dan menerima gagasan/ide orang lain secara cermat, analisis, kritis dan evaluatif untuk mempertajam pemahaman. Sedangkan menurut Yulia (2016) kemampuan komunikasi dapat diartikan sebagai suatu kemampuan siswa dalam menyampaikan sesuatu yang diketahuinya melalui peristiwa dialog atau saling hubungan yang terjadi di lingkungan kelas, dimana terjadi pengalihan pesan, pesan yang dialihkan berisi tentang materi matematika yang dipelajari siswa.

Kemampuan komunikasi matematis dapat diartikan sebagai kemampuan dalam menyampaikan sesuatu yang diketahuinya melalui lisan atau tulisan. Adapun indikator kemampuan komunikasi matematika yang digunakan dalam penelitian ini 
adalah 3 dari 6 indikator Lestari (2015) dalam melihat kemampuan komunikasi matematis peserta didik. Berikut indikator yang digunakan:

a. Menghubungkan benda nyata, gambar, dan diagram ke dalam idea matematika.

b. Menjelaskan idea, situasi, dan relasi matematika secara lisan atau tulisan, dengan bendanyata, gambar, dan aljabar.

c. Menyatakan peristiwa sehari-hari dalam bahasa atau simbol matematika.

Berdasarkan observasi awal yang dilakukan di MTS Negeri 02 kerinci bahwa kemampuan komunikasi matematis peserta didik masih rendah. Sebagaimana hal ini terlihat ketika peserta didik dihadapkan dengan soal kemampuan komunikasi matematis, yaitu diberikan 2 butir soal uraian kepada peserta didik.Pemberian tes tersebut dilakukan pada kelas VIIC MTS Negeri 02 Kerinci yang berjumlah 21 orang peserta didik. Berdasarkan tes kemampuan komunikasi tersebut, terlihat bahwasanya peserta didik tidak dapat memahami permasalahan didalam soal untuk mendaftarkan anggota-anggotanya dengan benar, sehingga terjadi banyak kesalahan untuk menggambarkannya di dalam diagram venn. Hasil analisis kemampuan komunikasi peserta didik hanya terdapat 4 orang peserta didik yang menjawab semua dengan benar, karena hampir semua sama tidak dapat memahami permasalahan yang ditanyakan oleh soal. Sehingga peserta didik tidak dapat memahami langkah-langkah untuk dapat mengilustrasikan himpunanhimpunan tersebut kedalam diagram venn dan menentukan irisannya yang terjadi pada penyelesaian tersebut. Terlihat dari hasil pensekoran bahwa kemampuan peserta didik dalam menghubungkan benda nyata, gambar dan diagram kedalam ide matematika pada soal 1 dengan presentase $50 \%$. Kemampuan peserta didik dalam menjelaskan idea, situasi, dan relasi matematika secara lisan dan tulisan, dengan benda nyata, gambar, dan aljabar pada soal 2 dengan presentase $46.4 \%$.

Dari hasil analisis diatas, dapat dikatakan bahwa kemampuan komunikasi matematis peserta didik MTS Negeri 02 Kerinci masih tergolong rendah.Ada beberapa yang menyebabkan peserta didik tidak bisa menjawab soal.Salah satu diantaranya pembelajaran yang kurang optimal yaitu model pembelajaran masih berpusat pada guru, sehingga guru menempatkan posisi aktif menjelaskan materi dan memberikan latihan. Sedangkan peserta didik hanya duduk mencatat dan mendengarkan apa yang disampaikan guru dan mengerjakan latihan yang diberikan. Sedikit peluang bagi peserta didik untuk mengkomunikasikan ide-idenya dalam pembelajaran matematika.Padahal ketika penulis melakukan observasi, kondisi MTS Negeri 02 Kerinci sudah menggunakan kurikulum 2013 (K-13) secara keseluruhan.Tentu hal ini sangat berbanding terbalik dengan yang diharapkan oleh K-13, dimana peserta didik yang seharusnya berperan aktif dalam pembelajaran.

Jika semua permasalahan tersebut dibiarkan, maka akan mengakibatkan nilai matematika selalu rendah, tidak terjalin interaksi yang baik antara guru dan peserta didik, sehingga komunikasi peserta didik tidak muncul selama pembelajaran. Oleh karena itu, untuk menyelesaikan masalah tersebut guru perlu memilih dan 
menerapkan suatu strategi pembelajaran yang meningkatkan kemampuannya dalam belajar secara aktif.Salah satu strategi pembelajaran yang dirasa dapat meningkatkan kemampuan komunikasi matematis siswa dalam pembelajaran matematika, adalah model pembelajaran Process Oriented Guided Inquiry Learning (POGIL).

POGIL merupakan model pembelajaran yang menggabungkan inkuiri terbimbing dengan pendekatan kooperatif (Maknun, 2018). Adapun kelebihan dari pembelajaran POGIL salah satunya dapat membantu peserta didik untuk lebih menemukan sendiri pengetahuannya. Selain itu juga dapat membantu peserta didik dalam meningkatkan ketrampilan proses, bertanya dan mengkomunikasikan pengetahuan. Oleh karena itu, pembelajaran POGIL diharapkan dapat mendorong peserta didik berpartisipasi aktif dalam pembelajaran, sehingga berpengaruh kepada komunikasi matematis peserta didik.

POGIL merupakan akronim dari Process Oriented Guided Inquiry Learning. Warsono \& Hariyanto, (2012) mengemukakan model POGIL pertama kali dikembangkan di Franklin dan Marshall College State University of New York oleh sekumpulan profesor yang dipimpin oleh Richard S. Moog dan bekerja sama dengan profesor lain dari Stony Brook University, antara lain David M. Hanson pada tahun 1994.

POGIL merupakan model pembelajaran yang menggabungkan inkuiri terbimbing dengan pendekatan kooperatif. Menurut Fitriani, dkk (2017) model pembelajaran POGIL dilaksanakan dengan pendekatan kooperatif yang didesain dengan kelompok kecil dan berinteraksi dengan guru sebagai fasilitator. Anggota kelompok dalam model POGIL terdiri 3 atau 4 peserta didik. Setiap anggota kelompok dalam pembelajaran model POGIL memiliki peran-peran yang berbeda sehingga dalam pembelajaran setiap peserta didik akan dituntut untuk berperan secara aktif sesuai dengan peran yang diperoleh dalam kelompoknya Rahayu, D.P.dkk (2015). Selain itu, Widyaningsih dkk (2012) menyatakan pembelajaran POGIL mampu mengembangkan keterampilan, berpikir tingkat tinggi dan metakognisi, komunikasi, kerja tim, manajemen dan penilaian serta tidak lagi mengandalkan hapalan, tetapi pengembangan keterampilan untuk sukses dalam pembelajaran.

\section{METODE PENELITIAN}

Adapun untuk desain penelitian, penulis menggunakan The Non-equivalent Posttest Only Control Group Design.Eksperimen dilakukan pada dua kelas, yakni kelas eksperimen dan kelas kontrol. Pada kelas eksperimen diberi perlakuan model pembelajaran POGIL, sedangkan kelas kontrol menggunakan metode konvensional. Rancangan perlakuannya adalah:

Tabel 1. Rancangan Penelitian

\begin{tabular}{crcc}
\hline No & Kelas Sampel & Perlakuan & Tes akhir \\
\hline 1. & Kelas Eksperimen & $\mathrm{X}$ & $\mathrm{T}$ \\
\hline 2. & Kelas Kontrol & $\mathrm{Y}$ & $\mathrm{T}$ \\
\hline
\end{tabular}


Keterangan:

$\mathrm{X}=$ kelas eksperimen (model pembelajaran POGIL)

$Y=$ kelas kontrol (pembelajaran Konvensional)

$\mathrm{T}=$ Tes akhir

Populasi dalam penelitian ini adalah peserta didik kelas VII MTS Negeri 02 Kerinci. Sampel yang diambil dalam penelitian ini adalah dua kelas, yang terdiri dari kelas eksperimen dan kelas kontrol. Agar penelitian ini lebih terpusat serta menjadi sasaran maka penelitian dilaksanakan terhadap sampel yang mewakili dari populasi, pengambilan sampel dilaksanakan dengan caracluster random sampling. Setelah diketahui populasi berdistribusi normal, memiliki varians yang homogen dan memiliki rata-rata nilai yang sama, maka didapatkan kelas eksperimen dan kelas kontrol, dan kedua kelas dijadikan sebagai kelas sampel, yaitu kelas VII A sebagai kelas eksperimen dan kelas VII C sebagai kelas kontrol. Dimana kelas eksperimen yang diajarkan dengan menggunakan model pembelajaran POGIL dan kelas kontrol diajarkan menggunakan model pembelajaran konvensional.

Adapun teknik pengumpulan data pada penelitian ini adalah tes. Tes yang digunakan untuk mengetahui kemampuan komunikasi matematis peserta didik dalam penelitian ini adalah tes menggunakan soal essai, tes tersebut terlebih dahulu diujicobakan pada kelas VIII MTS Negeri 02 Kerinci, dari uji coba tersebut dianalisis validitas, daya pembeda, tingkat kesukaran, dan reliabilitasnya, kemudian soal yang memenuhi tes dipakai dan soal yang tidak memenuhi syarat tidak dipakai. Analisis data dalam penelitian ini adalah menggunakan uji-† satu sampel dan uji-† dua pihak, dimana uji prasyarat yaitu uji normalitas dengan menggunakan uji Liliefors dan uji homogenitas dengan menggunakan uji F.

\section{HASIL DAN PEMBAHASAN}

Penelitian ini dilaksanakan dikelas VII semester II di MTs Negeri 02 Kerinci yang dilakukan di dua kelas sampel yaitu kelas VIIA sebagai kelas eksperimen atau kelas yang menggunakan model pembelajaran POGIL (Process Oriented Guided Inquiry Learning), dan kelas VIIC sebagai kelas kontrol atau kelas yang menggunakan model pembelajaran konvensional (Ekspositori). Deskripsi data posttest kelas eksperimen dan kontrol dapat dilihat pada tabel 2:

Tabel 2. Deskripsi data posttest

\begin{tabular}{lccccc}
\hline Kelas & $\begin{array}{c}\text { Skor } \\
\text { Ideal }\end{array}$ & $\bar{X}$ & $\boldsymbol{S}$ & $\mathbf{X}_{\text {mak }}$ & $\mathbf{X}_{\text {min }}$ \\
\hline Eksperimen & 100 & 83,57 & 12,36 & 100 & 55 \\
\hline Kontrol & 100 & 73,33 & 10,99 & 95 & 45 \\
\hline
\end{tabular}

Keterangan:

$\bar{X} \quad$ : Rata-rata

$S^{2} \quad$ : Varians

$X_{\text {mak }}$ : Nilai tertinggi

$X_{\min } \quad$ : Nilai terendah 
Dari tabel 2 didapatkan standar deviasi untuk eksperimen lebih tinggi dari kelas kontrol, karena kelas eksperimen ini memiliki rata-rata yang lebih baik dari kelas kontrol. Penarikan kesimpulan untuk tes pada penelitian ini dilakukan dengan menganalisis data hasil penelitian melalui uji hipotesis secara statistik dengan ujit.Sebelum uji hipotesis terlebih dahulu dilakukan uji normalitas dan uji homogenitas pada kedua kelas sampel. Data yang akan dianalisa diperoleh dari nilai kelas kontrol dan nilai kelas eksperimen yang telah dilaksanakan pada kelas sampel.

Berdasarkan perhitungan dikelas eksperimen diperoleh nilai $L_{0}=0,1021$ dan $L_{\text {tabel }}=$

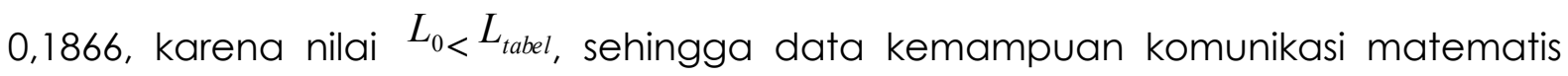
peserta didik kelas eksperimen berdistribusi normal. Sedangakan perhitungan dikelas kontrol diperoleh nilai $L_{0}=0,1104$ dan $L_{\text {tabel }}=0,1866$, karena nilai $L_{0<} L_{\text {tabel }}$, sehingga data kemampuan komunikasi matematis peserta didik kelas kontrol berdistribusi normal. Uji homogen variansi, uji ini dilakukan dengan membandingkan antara variansi terbesar dengan variansi terkecil. Sehingga didapatkan harga $\mathrm{F}_{\text {hitung }}=$ 1,2785 dan $\mathrm{F}_{\text {tabel }}=2,045$ untuk taraf $\propto=0,05$. Karena $\mathrm{F}_{\text {hitung }}<\mathrm{F}_{\text {tabel }}$. Sehingga dapat disimpulkan bahwa variansi kelas eksperimen dan kontrol adalah homogen.

Setelah memperoleh varians yang homogen, selanjutnya dilakukan uji rata-rata sebagai uji hipotesis menggunakan uji t. Hipotesis diatas diuji dengan menggunakan statistik one sample t-test, dengan hasil hipotesis sebagai berikut:

\section{Hipotesis 1}

Dari hasil uji hipotesis satu pihak, bahwa kamampuan komunikasi matematis dengan menggunakan model pembelajaran POGIL berdasarkan perhitungan yang diperoleh $t_{\text {hitung }}=5,028>t_{\text {tabel }}=1,725$ untuk taraf 0,05 dan dk $=\mathrm{n}-1$ makaH $H_{o}$ ditolak dan sebaliknya $H_{a}$ diterima, artinya pembelajaran dengan model pembelajaran POGIL efektif terhadap kemampuan komunikasi matematis peserta didik kelas VII MTs Negeri 02 Kerinci.

Model pembelajaran POGIL menuntut peserta didik terlibat secara aktif untuk bekerjasama dalam kelompok kecil dan memungkinkan kelompok tersebut mendapatkan bimbingan dari guru jika menemukan kesulitan dalam eksplorasi (inquiri terbimbing). Dalam pembelajaran POGIL peserta didik diberi kesempatan untuk mendiskusikan materi yang telah dicari. Sehingga setelah mendiskusikan dan bertanya kepada guru peserta didik dibagikan lembar permasalahan yang berupa soal yang telah dipilih dari buku paket. Sehingga dari soal tersebut peserta didik dapat melatih pemahamannya tentang materi yang telah mereka pahami bersama anggota kelompok. Selanjutnya guru akan memberikan materi tambahan dan meminta peserta didik untuk mempersentasekan hasil diskusinya ke papan tulis.

Pada model pembelajara POGIL peserta didik dituntut untuk mempersentasikan hasil diskusi yang telah didiskusikan bersama kelompok. Lalu peserta didik menjelaskan kepada teman-teman lainnya tentang hasil yang didapat, sehingga peserta didik yang lain dapat memperhatikan dan mengkoreksi hasil masing-masing diskusi 
kelompok mereka. Dimulai dari menghubungkan pengetahuan sebelumnya, maka membuat peserta didik lebih memahami tentang materi yang telah dipelajari dan ditambah lagi setiap peserta didik yang memiliki peran masing-masing dapat bertukar pikiran. Sehingga proses pembelajaran akan benar-benar berlansung dengan baik. Berdasarka penelitian terdahulu Khofifatunnisa' aktivitas peserta didik dalam pembelajaran POGIL termasuk dalam kriteria baik. Sehingga kemampuan matematis setelah diterapkan pembelajaran POGIL juga lebih baik jika dibandingkan kemampuan komunikasi matematis sebelum diterapkan pembelajaran. Oleh karena itu, dapat disimpulkan bahwa model pembelajaran POGIL memberikan hasil yang efektif terhadap kemampuan komunikasi matematis peserta didik kelas VII MTs Negeri 02 Kerinci. Hal ini sejalan dengan penelitian yang dilakukan Octaria (2018) yang mengatakan model pembelajaran POGIL lebih baik dari pada model konvensional di SMP Negeri 87 Jakarta Tahun 2017/2018.

\section{Hipotesis 2}

Dari hasil uji hipotesis satu pihak, bahwa kamampuan komunikasi matematis dengan menggunakan model pembelajaran Konvensional (Ekspositori) berdasarkan perhitungan yang diperoleh $t_{\text {hitung }}=1,389<t_{\text {tabel }}=1,725$ untuk taraf 0,05 dan dk $=\mathrm{n}-1$ maka $H_{o}$ diterima, artinya pembelajaran dengan model pembelajaran konvensional tidak efektif terhadap kemampuan komunikasi matematis peserta didik kelas VII MTs Negeri 02 Kerinci.

Hal ini terlihat pada saat proses pembelajaran dari pertemuan pertama sampai pertemuan keempat tidak terlihat adanya perubahan peningkatan kemampuan komunikasi peserta didik dimana pada pertemuan pertama peserta didik kurang memberi respon dari setiap tugas dan pertanyaan yang diberikan oleh guru, hal ini disebabkan guru lebih aktif sementara peserta didik pasif. Begitu juga pada pertemuan selanjutnya aktivitas pembelajaran yang dilakukan peserta didik masih sama seperti pada awal pertemuan dimana kurangnya pemahaman terhadap materi, menginterprestasikan dan juga dalam mengungkapkan ide-ide baik secara lisan dan tulisan dan pada saat mengerjakan latihan peserta didik hanya mengandalkan catatan saja.

Pembelajaran dirasa kurang efektif karena peserta didik yang mengerti menyelesaikan soal-soal latihan, sementara yang tidak mengerti berdiam diri menunggu jawaban dipapan tulis atau menyalin jawaban temannya. Sehingga membuat peserta didik tidak aktif dalam proses pembelajaran. Dapat disimpulkan bahwa model pembelajaran konvensional kurang efektif terhadap kemampuan komunikasi matematis peserta didik kelas VII MTs Negri 02 Kerinci. Alasannya karena model pembelajaran konvensional lebih kepada guru yang aktif dan peserta didik tidak dapat aktif dalam proses pembelajaran.

\section{Hipotesis 3}

Karena kedua kelas berdiskusi normal dan homogen maka dapat dilakukan pengujian hipotesis 3 dengan rumus uji- $\dagger$ dua sampel. Pengujian hipotesis ketiga menggunakan independent sample t-test.Hipotesis ketiga menganalisis data posttest 
kelas eksperimen yang menerapkan model pembelajaran POGIL dan data posttest kelas kontrol yang menerapkan model konvensional (Ekspositori). Berdasarkan analisis uji $\dagger$ perhitungan dapat kita lihat di Lampiran diperoleht $t_{\text {hitung }}=8,7559$ dan $t_{\text {tabel }}=$ 2,021 untuk taraf signifikasi 0,05dan derajat kebebasan (dk) $=n_{1}+n_{2}-2$. Dari hasil tersebut kita bandingkan dengan kriteria pengujian $H_{o}$ jika $t_{\text {hitung }}=2,775$ dan $t_{\text {tabel }}=$ 2,021 sehingga $t_{\text {hitung }}>t_{\text {tabel }}(2,775>2,021)$ maka berdasarkan kriteria pengujian disimpulkan $H_{o}$ ditolak dan sebaliknya $H_{a}$ diterima. Sehingga dapat disimpulkan bahwa terdapat perbedaan keefektifan model pembelajaran POGIL dan model pembelajaran konvensional (ekspositori) terhadap kemampuan komunikasi matematis peserta didik kelas VII MTs Negeri 02 Kerinci.

Pada penerapan model pembelajaran konvensional tidak efektif dikarenakan pembelajaran yang diterapkan merupakan pembelajaran yang biasa diterapkan oleh guru, dimana guru mendominasi kegiatan pembelajaran, defenisi, rumus yang diberikan oleh guru, dan contoh - contoh yang diberikan dan dikerjakan pula sendiri oleh guru dengan cara menjelaskan dan peserta didik meniru cara kerja dan cara penyelesaian yang dilakukan oleh guru. Pembelajaran ini lebih menekankan pada guru saja sebagai sumber utama, sehingga ketika dilakukan tes akhir rata-rata kemampuan komunikasi matematis dengan menggunakan model konvensional didapatkan rendah dari model pembelajaran POGIL.

Dalam proses pembelajaran POGIL guru memberikan kesan positif terhadap pelaksanaan pembelajaran. Peserta didik lebih antusias dalam belajar, lebih aktif, dan bisa bekerja sama dengan baik. Hal ini disebabkan karena peserta didik lebih memiliki kesiapan awal berupa pengetahuan konsep awal sub materi yang akan dipelajari. Oleh karena itu berbanding terbalik dengan model pembelajaran konvensional karena peserta didik belum memiliki kesiapan dalam belajar, peserta didik hanya menerima apa yang disampaikan guru. Adapun peran guru dalam model pembelajaran POGIL bukanlah sebagai ahli yang bertugas untuk mentransfer pengetahuan, melainkan sebagai pembimbing peserta didik dalam proses pembelajaran, menuntut peserta didik untuk mengembangkan keterampilan, serta membantu peserta didik dalam menemukan atau mengembangkan pemahamannya sendiri dari proses yang mereka lakukan.

Kedua model yang diterapkan terdapat perbedaan, dengan menggunakan model POGIL lebih baik dari model konvensional. Hal ini sejalan juga dengan penelitian Nisa (2018) yang mengatakan model POGIL termasuk dalam kriteria baik, sehingga ratarata kemampuan komunikasi matematis setelah diterapkan pembelajaran model POGIL juga lebih baik dibandingkan kemampuan komunikasi matematis sebelum diterapkan pembelajaran. 


\section{KESIMPULAN DAN SARAN}

Berdasarkan rumusan masalah yang diajukan dan hasil penelitian yang didapat, maka dapat ditarik kesimpulanModel pembelajaran Process Oriented Guided-Inquiry Learning (POGIL) efektif terhadap kemampuan komunikasi matematis peserta didik kelas VII MTs Negeri 02 Kerinci.Model pembelajaran konvensional (Ekspositori) tidak efektif terhadap kemampuan komunikasi matematis peserta didik kelas VII MTs Negeri 02 Kerinci.Terdapat perbedaan model pembelajaran Process Oriented GuidedInquiry Learning (POGIL) dan model pembelajaran konvensional (Ekspositori) terhadap kemampuan komunikasi matematis peserta didik kelas VII MTs Negeri 02 Kerinci.

\section{DAFTAR PUSTAKA}

Deswita, R. dkk., (2018). Peningkatan Kemampuan Komunikasi Matematis Siswa Melalui Model Pembelajaran CORE dengan pendekatan Scientific. Jurnal Riset Pendidikan Matematika. 1 (1).35-43.

Fitriani, W. dkk., (2017), Perbandingan Model Pembelajaran Process Oriented Guided Inquiry Learning (POGIL) dan Guided Inquiry (GI) Terhadap Keterampilan Berpikir Kritis Siswa. Jurnal Riset Pendidikan Kimia, Vol.7 no.1, hlm. 76-84

Handayani, A. dkk., (2014). Analisis Kemampuan Komunikasi Matematis Siswa melalui Pendekatan Pendidikan Matematika Realistik (PMR) Bagi Siswa Kelas VII MTsN Lubuk buaya padang tahun pelajaran 2013/2014, Jurnal pendidikan Matematika, Vol.3 No.2, hlm.1-6

Hasratuddin, (2014).Pembelajaran Matematika Sekarang dan Yang Akan Datang Berbasis Karakter. Jurnal Didaktik Matematika, Vol.1 No.2, hlm.30-42.

Lestari, K.E. (2015). Penelitian Pendidikan Matematika, Bandung: PT Refika aditama.

Maknun, H.L.dkk., (2018), Analisis POGIL (Process Oriented Guided inquiry Learning) sebagai model dalam melatihkan keterampilan berpikir kritis siswa SMA. Inovasi Pendidikan Fisika, hlm. 320-324

Navia, Y., \& Yulia, P. (2017). Hubungan Disiplin Belajar dan Konsentrasi Belajar Terhadap Hasil Belajar Matematika Siswa. Pythagoras: Jurnal Program Studi Pendidikan Matematika, 6(2).

Nisa, K. (2018). Pengaruh model Process Oriented Guided Inquiry Learning (Pogil) berbasis etnomatematika terhadap kemampuan komunikasi matematis peserta didik (Doctoral dissertation, UIN Sunan Ampel Surabaya).

Octaria, E. A. (2018). Pengaruh Model Process Oriented Guided Inquiry Learning (Pogil) Terhadap Kemampuan Berpikir Kritis Matematis (Bachelor's thesis, Jakarta: FITK UIN Syarif Hidayatullah Jakarta). 
Rahayu, D.P.dkk., (2015). Pengaruh Model Pembelajaran Process Oriented Guided Inquiry Learning Terhadap Kemampuan Berpikir Kritis Peserta Didik pada Materi Perubahan Benda. Unnes Science Education Journal, Vol.4 No.3. hlm 936-944

Sari, R. N. (2020). Profil Kemampuan Berpikir Logis Matematis Mahasiswa Program Studi Pendidikan Matematika Universitas Pasir Pengaraian. Jurnal Absis: Jurnal Pendidikan Matematika Dan Matematika, 2(2), 188-193.

Warsono \& Hariyanto. (2012). Pembelajaran Aktif. Bandung: PT Remaja Rosdakarya.

Widyaningsih, S.Y. dkk.,(2012). Model MFI dan POGIL ditinjau dari aktivitas Belajar dan Kreativitas Siswa terhadap Prestasi Belajar. Jurnal Inkuiri, Vol.1 No.3, hlm. 266275

Yulia, P., \& Luqman, M. (2016). Pengaruh Model Pembelajaran Quantum Tipe Visual Auditory Kinesthetic (Vak) Terhadap Kemampuan Komunikasi Matematis Siswakelas VII SMP Negeri 17 Batam Tahun Pelajaran 2013/2014. Pythagoras: Jurnal Program Studi Pendidikan Matematika, 4(2).

Yulia, P. (2016). Efektifitas Model Pembelajaran CTL (Contextual Teaching And Learning) Terhadap Kemampuan Pemecahan Masalah Matematis Siswa Kelas VIII SMP N 16 Batam Tahun Pelajaran 2014/2015. Pythagoras: Jurnal Program Studi Pendidikan Matematika, 5(1). 